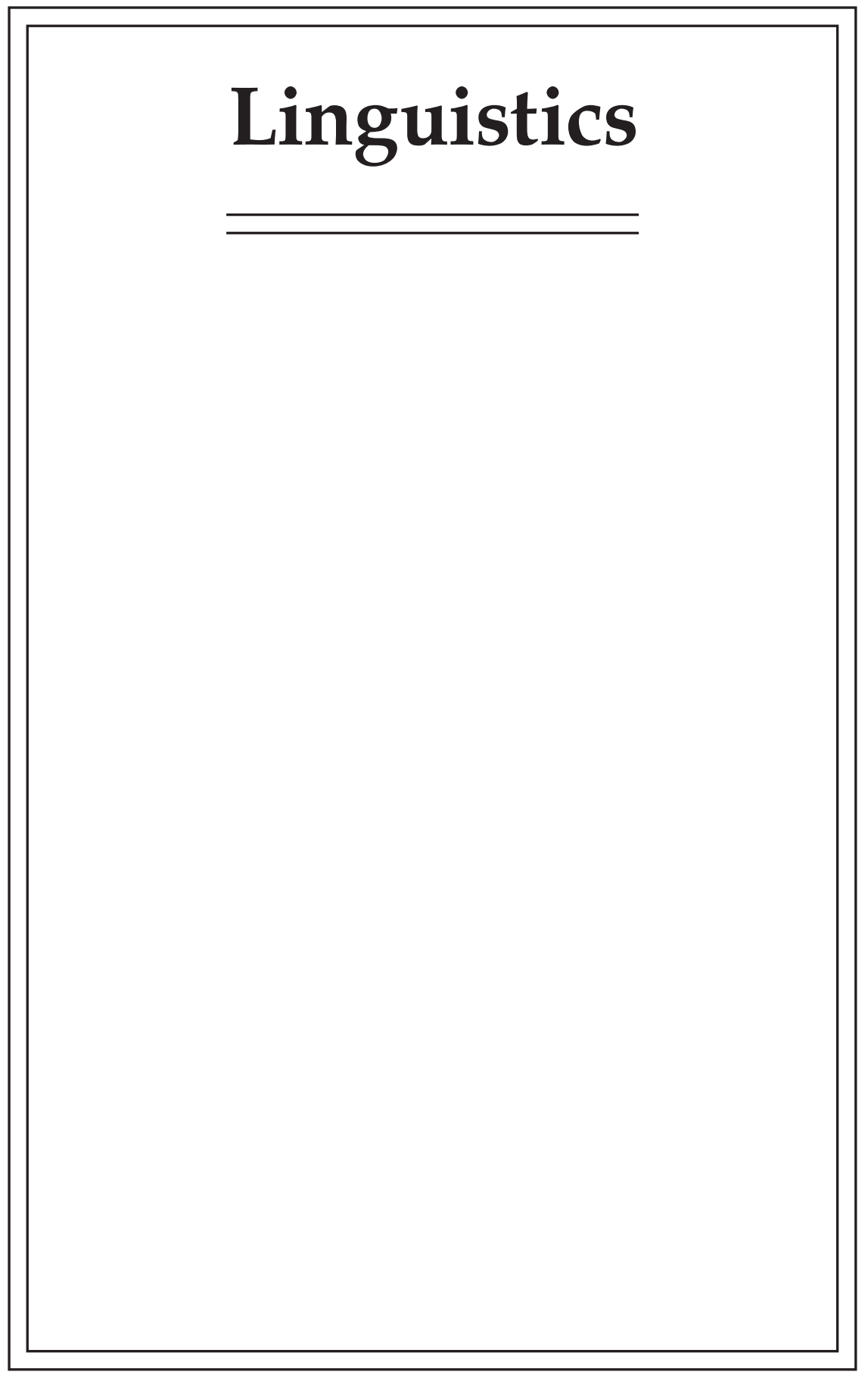

Downloaded from Brill.com๑4/26/2023 12:34:10PM via free access 
Maria Bulakh

Institute for Information Transmission Problems

Moscow

\section{SEMANTIC SHIFTS IN THE LEXICAL FIELD OF TASTE IN GEEZ}

The present contribution ${ }^{1}$ deals with the semantic shifts in the lexical field of taste, based on the synchronic and diachronic analysis of taste terms of Geez (Old Ethiopic). The preliminary discussion concerns the main features of the lexical field of taste (in comparison to the lexical field of colour) and factors influencing its evolution. The first part contains a list of Geez roots used to describe various shades of taste, ${ }^{2}$ along with a short discussion of their semantics in Geez and with etymological data. In the second part of the paper, the semantic developments attested in the analyzed roots are summarized. For the typological evaluation of the collected data a similar investigation on the material of Mongolian, Turkic and Indo-European languages carried out by I. Gruntov (ms.) and the relevant parts of a work on semantic shifts by M. Razuvaev (2004) were used.

Some remarks on the semantic structure of the lexical field in question are necessary. In the course of the investigation a strong similarity between the lexical fields of taste and colour has been observed (a research of the Geez colour terms has been carried out by the present author, see Bulakh forthcoming). This is by no means surprising, since tastes and colours have much in common, being sensory experiences, perceived by organs of taste and vision respectively. Both taste and colour concepts are expressed mostly by adjectives and by verbs of state. Both colour and taste names constitute structured systems, whose core consists of so-called basic terms and whose peripheral zone may be expanded through adding new members with the help of certain derivational devices (for colours, see the seminal work by Berlin and Kay

${ }^{1}$ The research is carried out within the framework of the project «Semantic shifts in the languages of the world», supported by the RFBR, grant \# 03-06-08133a; for the general description of the project, see ZALIZNIAK 2001 [for the list of abbreviations used in this article see p. 349]. I would like to express sincere gratitude to my teacher L. Kogan, who carefully read and corrected the preliminary version of the paper. I am thankful to I. Gruntov and M. Razuvaev for their comments and improvements. Special thanks go to D. Nosnitsin, who provided me with some Geez sources. Needless to say, all possible mistakes are my own responsibility.

${ }^{2}$ Terms with meaning 'insipid, tasteless' are considered here too: although, strictly speaking, they do not refer to any kind of taste, they doubtlessly belong to the lexical field of taste. 
1969; for tastes, see Gruntov, ms.). For both fields, the concept of prototype is crucial, that is, of an object that normally represents the best sample of the designated quality (for colour terms, see Wierzbicka 1996:160, 287-334). Thus, comparative constructions are typical for colour names, as well as for taste names, e. g., black as soot, sweet as honey etc. The prototypes are frequently involved in the semantic developments taking place in both fields. Their designations can be used to form new colour or taste names; and vice versa, lexemes with semantics of colour or taste may derive names for their prototypes. For colours, the process is well-known (cf. such English terms as lemon-coloured or saffron-coloured). Similar derivative strategy is attested in the lexical field of taste. Words denoting salty taste usually go back to the names of its prototype, salt (Gruntov, ms.; Razuvaev 2004:114f.). For some terms, the connection with a certain object can only be traced etymologically. Thus, Russian пряный 'spiced, spicy, hot' is derived from nepeu 'pepper' (Vasmer 341). The reverse process, that is, of naming prototypes after their taste qualities, is also attested, cp., for instance, Arb. hummād - 'oseille' (BK I 493), 'sorrel' (Lane 645) < hamada 'être acide' (BK I 492, Lane 644).

Another factor influencing the semantic developments in the names of colours and tastes is the connotations. Colour names and taste names often possess strong positive or negative associations and demonstrate them not only in their usage, but in the semantics of their derivatives and/or of their cognates as well. However, the taste names are more directly related to the evaluative meanings, which are in several cases included into the core of their semantics. It is obvious that the pragmatical necessity of a positive or negative evaluation of a kind of taste is higher than that of the evaluation of a colour: tastes constitute essential characteristics of food and drink and give us important information on the quality of the objects to be defined. Therefore, the primary classification of tastes will divide them into two classes: «good» ones, that is, signalizing that the food/drink can be consumed, and «bad» ones, that is, informing of a danger of poisoning (see Razuvaev 2004:122f., Gruntov, ms., Viberg 1984:152-155).

The next point of similarity between taste and colour terms is the existence of certain objects that usually can be qualified by a limited number of taste or colour terms, and that slightly change the meaning of the terms in question. It has been observed that colour terms lose their direct meaning when applied to certain objects. Thus, the French colour term blanc 'white', when applied to wine, does not refer to literally white wine, but rather to a yellowish one: it is the opposition between two types, vin rouge vs. vin blanc, that is important in this case. It is evident that colour terms, when used not to describe an object, but rather to classify it, can alter their reference and hence, need special treatment.

Taste terms can also sometimes classify certain items of food/drink, and can then be used in a new meaning. A well-known case is the designation of 
two kinds of water: river (drinkable) vs. sea (undrinkable) water are referred to in many languages with the help of taste names, which, however, experience a certain change of meaning in the application. Drinkable water can be described with a term originally meaning 'sweet' (cf. English sweet water, German Süßwasser, cf. also Arb. hulw- 'doux, sucré', BK I 484, which can be a qualifier to water, $m \bar{a}$ ?-un hulw-un, 'sweet (drinkable) water'; see also Gruntov, ms., Razuvaev 2004:121f.). Although Gruntov argues that river water is indeed perceived as sweet when tasted immediately after salty water, it cannot be denied that an average English speaker calling the water sweet hardly refers to a taste similar to that of sugar. In Semitic languages, taste terms denoting a pleasant taste (without definite reference to a specific taste) are often employed to denote this kind of water. Thus, in Arabic drinkable water is frequently designated as $m \bar{a} 1$-un Sad $\underline{d} b-u n$ (BK II 198, Lane 1981), whereas the root $\hat{q} \underline{d} b$ conveys the idea of pleasant, excellent (but not necessarily sweet) taste: e. g., the expression ?al-?a@dabāni, lit. 'the two most sweet things', refers to saliva and wine (Lane 1083). In Tigrinya, sweet water can be described as tofum 'tasty, savoury' (see I.9). Another example of classification with the help of taste terms is the nomination of two types of dough leavened vs. unleavened - with adjectives whose primarily meanings are 'sour' and 'insipid' respectively, cf. Russian пресный 'insipid; unleavened (dough, bread)', see also I.1. At the same time, another strategy, employing primary meaning 'sweet' to denote unleavened bread may be found as well (see, for instance, I.7).

\section{Geez lexemes used to define the varieties OF tastes.}

\section{1. bəhi? 'vinegar, acid' (LGz. 90), 'acidus, acer' (LLA 498)}

The adjective is derived from the verb bəh $P a$ 'to be fermented, ferment, turn sour' (LGz. 90, LLA 498). Thus, the root primarily denotes the chemical process, fermentation, which is usually associated with sour taste (see II.2). The adjective bohi $?$ is normally applied to various kinds of liquids subject to the process of fermentation: Pomənna bəhi? wayn wa-?әmonna bəhi? mes (Num. 6:3) 'from sour (fermented) wine and sour (fermented) mead', to render Gr. óxos ex oínou kaí óxos ek sikera 'vinegar of wine and vinegar of cider'. However, it could be applied as a purely taste adjective: wa-nāita məsla hamla bəhi? təballə\{u (Ex. 12:8) 'and they shall eat unleavened bread with sour herbs' where the genitive construction hamla bəhi?, lit. 'the herbs of the sour' is used to render Gr. pikrídón 'bitter herbs', from pikrós 'bitter'.

The term has no convincing etymology outside Ethiopian Semitic. Within the Ethiopian Semitic group, verbs with identical or related semantic and similar formal appearance (although demonstrating no regular correspondence) can be found. Formally, they reflect two consonantal roots: 


\section{1) bhk:}

Tna. bähak ${ }^{w} \ddot{a}, b a h a k^{w} \ddot{a}$ 'to be leavened (dough), to rise, to ferment (batter), become fermented', bəhuk 'leavened (dough), dough, paste; leaven, ferment, fermented batter; fig. lazy, weak person' (KT 1105).

2) $b k(k)$ :

Amh. bokka 'to ferment (batter); to become rancid (butter); to become thick and sticky (mud used to plaster the walls of a house); to be ready for use (traditional ink)' (K 923), buho, buko, bəho 'fermented dough for making dabbo-bread' (ibid. 855);

Gur. Cha. Gyt. $b^{w a ̈ k a, ~ E z ̌ a ~ G o g . ~} b^{w a ̈ k k a, ~ E n m . ~ b o k a, ~ W o l . ~ b o k e, ~ M u h . ~}$ Msq. Sod. bokka, End. bokkā, Sel. bōkke, Zwy. boh̄u 'ferment' (LGur. 135).

The most plausible solution is to regard these Ethiosemitic terms as loanwords from various Cushitic lexemes meaning 'to ferment' (Oromo, Highland East Cushitic) or 'to rot, stink' (Agaw, Saho), possibly with contamination of these two roots (the process of rotting, decaying is also frequently associated with sour taste, see II.2):

Burji boh-aaw- 'ferment', boh-ees- 'ferment' (Hud 181); Kambata bukeek- 'ferment', buk-ees- 'ferment' (ibid. 311); Oromo bukoo 'dough, batter' (Gragg 65; according to Sasse 42, borrowed into Burji bukk-aaw- 'be kneaded', bukk-ays- 'knead');

Quara bohŭ 'faulen, stinken' (Reinisch 1885:42); Saho bah 'faulen, stinkend werden' (Reinisch 1890:72); possibly borrowed into Ethiosemitic with reduplication: Gez. ba $\chi^{\text {w } b a \chi}{ }^{w} a$ etc. 'decay, become putrid' (LGz. 96, LLA 517); Tna. bahbohe 'to stink, give off a bad, unbearable odor (goats in the rutting season, man); to pour, pour out brusquely, to flow vigorously, gush out; to splash, splatter, sprinkle (water) here and there' (KT 1106).

2. losuh insipid, flavourless, tasteless, ineffective, used up, worn-out', lasha 'be insipid, be unseasoned, be tasteless, lose its saltiness, be flavorless, be ineffective, be inefficient, be harmless, be nonsense, be used up, be worn-out, blunder, fail (strength)', ləshat 'insipidity, folly' (LGz. 318, LLA 38).

This root is used to designate lack of taste; figuratively it is used to denote the absence of some important ingredient. In the contexts quoted in LLA 38 it is opposed to the quality of saltiness: wa-?әmma-ssa dew lasha ba-mont ?ənka yəkassəməwo (Matth. 5:13) 'but if the salt becomes insipid, with what will they return taste to it?'; dew za-?at Iamo la-losuh (LLA 38) 'salt that has given taste to the tasteless'; loshata nafsəya kəsəmi ba-dew (Grohmann 1919 168) 'make the insipidity of my soul salty with salt'. A passage in the Book of Sirach demonstrates both the original meaning of taste and the figurative meaning 'ineffective, lacking smth. important': wa-za-ssa yənabbəb ba-kama rakaba yālassəh rə?əso wa-?albo mogasa kālu; wəsta ?afuhomu la-?abdān ləsuh [v. yəlassəh] nagar (Sir. 20:19) 'and this one is speaking as he has 
found, he is making himself ineffective, and there is no blessing of his voice; the speech is insipid in the mouth of the stupid people'; wa-wosta ?afühu laPabd yolassoh Pamsāl (Sir. 20:20) 'and the proverb is insipid in the mouth of the stupid'. At the same time, Dillmann quotes a passage where the adjective is obviously used in a purely figurative meaning, without any reference to

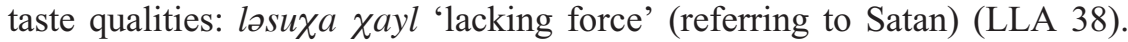
The root is also used several times in contexts with the noun məkr 'judgment, understanding' (often associated with the taste of salt, see II.5): təlass $ə$ h məkromu la-tabibān (Jes. 19:11, see LLA 37) 'the wisdom of the wise men loses its savour'.

The above quoted passages from Sirach demonstrate the definitely negative connotations of the root. Still, the verb Palsaha (causative to lasha), used in sense 'to render ineffective', may be applied to such objects as poison (?alsəh həmza za-kaYawa katäli 'make ineffective the poison that the murderer poured'), devils (Pogzi?abher yālsohkəmu Po-?agānont 'let the God make you ineffective, oh devils') or fetters (ba-hāymānota zi?ahu ?alsəha k'ollo mawäkəhtihu 'with his faith he loosened all his fetters', ibid. 38).

Another question is the possibility of a connection between the meanings 'insipid' and 'smack the lips, chew saliva' (LGz. 318), which Leslau considers to belong to a homonymous verb lasha, while Dillmann quotes it under the same entry as lasha 'to be insipid' (LLA 37). The only passage quoted by Dillmann for this meaning is Sir. 34:16: wa-bolā kama bəPəsi tabib za-śar@u laka; Ri-təlsāh ?ənza təmaş̦̣ər kama ?i-tāṣlə?o la-biṣəka 'and eat as a wise man that which they placed before you; don't smack your lips when you are chewing lest you revolt your neighbour'. Dillmann reconstructs the meaning 'saliva' as the primary semantic component of the root, deriving from it the verbal meaning 'to have saliva in mouth, to make noise with saliva', on the one hand, and the attributive meaning 'to resemble the taste of saliva, to be tasteless, insipid', on the other hand. Doubtlessly, this conjecture is suggested by a similar semantic shift attested for the Proto-Semitic root *tpl 'to spit' (Sam. tpl 'to spit', Tal 959; Arb. tafala 'cracher (une salive fine)', tafl-, tufl-, tufāl- 'cracat de salive fine; écume', BK I 201; Mhr. təfül/yətufəl/yətfêl 'to spit', tofyōl 'spit, saliva', JM 400; Jib. tfol/ytófal/yótfal 'to spit'; tfol 'spit, saliva', JJ 269; Hrs. tefōl 'to spit', tefélltefeyōl 'spittle, saliva', JH 126) ${ }^{3}$ whose Hebrew reflex has the meaning 'insipid': tāpēl 'ungesalzenes, Fades' (HALAT

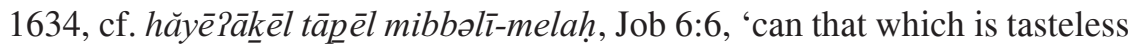
be eaten without salt?'), also attested in a figurative meaning 'useless, inef-

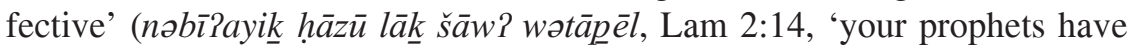
seen for you useless and tasteless things').

${ }^{3}$ The possibility of a connection with such meanings as 'slime', 'lime', 'to paste', as well as 'to slander' and 'to talk nonsense' requires a deeper study and will not be discussed here. 
Needless to say, this semantics corresponds exactly to that of the Geez root $l s h$. Thus, we are justified to postulate a semantic shift 'to spit' > 'to have the taste of saliva, to be insipid', with possible intermediate meaning 'saliva' (which is missing in the Geez root $l s h$, but is attested for the reflexes of the root *tpl in Arabic, Mehri and Jibbali).

The only etymological link for this root, an equation with Arabic salī 'insipide, qui n'a aucun goût', salā $a t-$ 'absence de goût d'un mets insipide' (BK I 1121, Lane 1404), with metathesis, has been suggested by Praetorius (1890:369).

3. ma Yar९ir 'sweet, sweet-tasting, honey-sweet' (LGz. 327, LLA 207).

This term is derived from the noun måār, maYar 'honey' (LGz. 326), using a pattern with reduplication of the last two radicals (the same adjective pattern is attested in Geez, e. g., in hamalmil 'green' < haml 'vegetation', LGz. 233, or damanmin 'dark, obscure' < damanā 'cloud', LGz. 135; for its usage in Semitic, see Barth 1967:218).

Honey as a prototype for sweet taste is, of course, widely used in the languages of the world (see Gruntov, ms.). An example of a taste name derived from the word for honey can be found in Akkadian: dašpu 'sweet' SB, NB (CAD D 120), 'honigsüß' (AHw. 165) < dišpu 'honey' from OA, OB on (CAD D 161), 'Honig' (AHw. 173). In Geez, the derivative ma Sar Yir is obviously used as an independent taste adjective 'sweet': e. g., in māya sark maSarYira sətay (Prov. 9:17, see LLA 207), 'water of theft is sweet for drinking', where the Geez adjective is rendering Gr. glukerós 'sweet'. Its belonging to the lexical field of taste is also testified by the opposition to marir 'bitter': zəntu Par?aya la-wəluda sab? marira wa-maSarSira (Hen. 69:8), 'this one showed the sons of men the bitter and the sweet'.

The term can be also applied to sounds with positive evaluation: yāred ma SarYira kāl (Grohmann 1919:76) 'Yārēd, sweet of voice', wa-ba?ənta kāala $m \bar{a}$ Yàr Sir za-surāfel (ibid. 259) 'and because of the sweet voice of Seraphim'.

The noun *maYar 'honey' is widely used in other Ethiosemitic languages, although only in Tigrinya is the taste meaning 'sweet' also attested:

Tna. mä̊ar 'honey; sweet, good', mäßarä 'to be sweet, be like honey' (KT 477).

Note also a further meaning development in Tigrinya: Pam Sarä 'to make sweet; to produce honey' > 'to be good for, be becoming, to suit, become one (ornament one is wearing)', e. g., in the following context: nəzu säb?ay šəlmat bəzuh yämə؟ərällu 'this person's ornate [dress] becomes him very well' (ibid.).

Tgr. maSar 'honey' (LH 135).

Amh. mar 'honey' (K 173).

Gur. Gog. $m^{w} \ddot{a} r$ 'beeswax' (LGur. 417), Enm. End. ma?ar, Cha. Gyt. mar, Gog. $m^{w} \ddot{a} r$ 'beeswax' (ibid.). 
Probably Har. $m \bar{a} r$ 'earwax' (LHar. 110) goes back to the same root, with the semantic development 'wax' (cf. Gurage, and below, Hebrew) > 'earwax'.

Outside Ethiosemitic languages, a likely cognate in Hebrew is attested, ya Sar 'Honigwabe' (HALAT 404). The semantic correspondence is all the more convincing in view of the meaning 'beeswax' attested in Gurage languages.

See further LGur. 386 (Gur., Gez., Tgr., Tna., Amh., Har.), LHar. 110 (Har., Gez., Tgr., Tna., Amh., Gur.).

4. madid 'acid, sour, angry, ill-tempered, rapacious' (LGz. 330, LLA 229), mədud 'fermented, sour' (LGz. 330), madda, madada 'ferment, be acid, be sour' (LGz. 330).

Of these lexemes, only the first is given in LLA. The latter two, although quoted in Grébaut 118f., are not provided with any textual reference. However, we can safely postulate the taste meaning 'sour, acid' for the term madid, provided by such examples as wa-?i-yəkawwən mașișa Palla lalla-gesamu yəśenni 'and it [wine] became not sour, on the contrary, it became better as each new morning appeared' (Budge 1906:20 [text], 50 [translation]); wayofarri fore madid (Jes. 18:5) 'and the sour [grape] brings fruits'; bəhi? madid 'sour acidity' (LLA 229). The adjective is also attested in a figurative meaning 'angry, ill-tempered': tak ${ }^{w}$ slāt marirān wa-madid̄ān 'bitter and sour wolves' (corresponding to Gr. lúkoi drimeis kaì pikroí) (ibid.).

In Tigrinya and Amharic we find exact phonetic correspondences, demonstrating identical semantics as well:

Tna. (both non-palatalized and palatalized variants are attested): mäsiș 'sour, bitter, tart, acid; vinegar', mäṣäsä 'to turn sour, get sour' (KT 536); mäçčäçä 'to turn sour (food), to go bad (food)'; mäçäăç bälä 'to become moldy (hay, etc. because it was not exposed to sun and air after getting wet)' (ibid. 529).

The primary meaning 'to be sour' is illustrated, for instance, by applications of the root to sour mead: mes mäsișu 'the mead has turned sour' or to the skin of a citrus fruit: moșșas 'the bitter or sour white inner skin of an orange or citrus fruit'. One should also note the figurative meanings in Tigrinya, such as 'sour-tempered' for mässiș 'sour'; 'sharp-tongued woman, termagant' for mäșsas (fem. of mäsisị); 'irony, sarcasm' for məșșät 'sourness'. An expression 'sour mouth' is used to refer to a harshly-speaking person: ?afu mäsis zə-konä 'one who speaks harshly, bitterly, sharptongued person', lit. 'the one who had a sour mouth' (ibid. 536).

Amh. (both reflexes with $d>t$ and $d>s$ are attested): mätit 'sour, vinegar, acid' (K 361), mätțäțä 'to ferment (batter), to turn sour, become sour, acid; to get angry' (ibid. 360); mäsis 'sour', mäșașa 'vinegar, lemon, bean-flour paste' (ibid. 370).

The examples attested in Kane's dictionary demonstrate not only the meaning 'to ferment, to turn sour', but also 'to become thick, stiff, hard': litu mätțäțä 'the batter fermented'; səga mätțäțä 'the meat became stiff, hard'; 
kuslu mätțätä 'the wound healed'; Paybu mäțtäṭä 'the ayb-cheese turned sour'; tälla matț ${ }^{\text {tal }}$ 'the beer has gone sour' (ibid. 361). The meaning 'to dry up' seems to be semantically related (however, it can also be derived from 'to suck, suck up', see below, or, most likely, appear as a result of the contamination of both roots 'to be sour' and 'to suck'): woha mätt t"al 'the water has almost dried up'; čokaw mätțätä 'the mud started to dry out'; mätața 'almost dry, nearly dried up; lean, scraggy, wizened (man, animal); sunken cheeked, having drawn or haggard features' (ibid. 361).

Outside Ethiopian Semitic, we find an Arabic term with a regular phonetic correspondence (suggesting a PS root $m \hat{s} \hat{s}$ ) and a practically identical meaning:

Arb. madad- 'lait aigre' (BK II 1119, Lane 2720), mumidd- 'qui pique, qui picote (vinaigre, collyre)' (BK II 1119), madd- 'qui cause de la douleur, du picotement (p.ex. collyre à l'oeil, vinaigre à la bouche)', madda 'faire du mal, piquer, picoter (se dit de l'action du collyre sur l'oeil ou d'un vinaigre trop fort, etc., sur la bouche)' (ibid. 1118).

Note that the Arabic root is usually used in the figurative meaning 'to hurt, to cause pain': madda 'affecter quelqu'un, lui causer de la peine (se dit des chagrins)' (ibid.), 'he suffered, or experienced, pain' (Lane 2719). The semantic development is obvious, the verb originally denoting the effect of tasting an acid food, cf. such context as madda $l-\chi a l l-u f \bar{a}-h u$ 'the vinegar burned his mouth' (ibid. 2720). The meaning became gradually applicable to other sensory experiences, e. g., tactile in Pal-kuhl-u yumiddu l-Sayn-a 'the collyrium pains the eye (or burns the eye)' (ibid.; see II.3), and, finally, was broadened into 'to cause pain', without any association with senses of perception, for instance in ražul-un madd-u d-darb-i 'Homme qui frappe fort et dont les coups se font sentir' (BK I 1118, Lane 2720), or Pimra?atun maddat-un 'a woman who does not bear, or endure, what displeases her, or grieves her; whom a small word pains; whom a small things hurts, or annoys' (Lane 2720). The comparison with Ethiosemitic terms justifies the claim that the taste semantic is primary in this case, whereas the figurative meaning demonstrates the strong negative connotations of the root. Cf. also muda $\bar{d}$ - 'eau très-salée' (BK II 1119, Lane 2720), which shows a semantic development 'acid, sour' > 'having an unpleasant taste'.

In view of the Arabic cognate showing the meaning 'to be painful, to cause pain', a comparison with Tgr. mașa 'to be ill, to suffer pain, to be tormented, to mourn' (LH 145), Gaf. mäșäsää 'être malade' (LGaf. 218), Arg. mätṭäta- 'be sick' (LArg. 214) is possible. Note, however, that alternatively they can be compared to Jib. múttos 'to become ill, unhealthy' (JJ 175), Arb. māsșat- 'sorte de maladie d'enfants...' (BK II 1114).

See further LGz. 331 (Gez., Arb., Hbr., Tna., Tgr., Amh.).

W. Leslau suggests a comparison to Hbr. mașșā 'Mazze: ohne Sauerteig schnell gebackenes Fladenbrot aus Gerstenmehl u. Wasser; das aus dem nicht 
verbrannten Anteil der minhāa am Heiligtum ohne Säuerung hergestellte, den Priestern vorbehaltene Brot' (HALAT 588), pB. mașsā 'unleavened bread, esp. the bread served at the Passover meal; a hide not tanned by a process of fermentation, untanned hide' (Ja. 823). However, this comparison is far from evident, since the essential component of the Hebrew lexeme is the absence of fermentation process, that is, the opposite of the semantics of Ethiosemitic and Arabic terms. It is more justifiable to connect the Hebrew term with the Proto-Semitic root *mș 'to squeeze, press, suck' ${ }^{4}$

Hbr. mīs 'Pressen' (HALAT 547).

pB. $m s y, m \bar{a} s \bar{a}$ 'to squeeze, wring, esp. to wring out the blood of the bird sacrifice' (Ja. 825), māṣaș 'to press, suck; to drain' (ibid. 827).

Jud. mūṣ 'to suck' (ibid. 746), myṣ 'to suck' (ibid. 778), moșī 'to wring; to suck' (ibid. 826), məṣaṣ 'to suck, drain; to wring, press' (ibid. 827).

JPA mș 'to suck' (Sokoloff 326).

Sam. mșyṣh 'sucking', mṣs 'to consume' (Tal 483).

Mnd. MS A 'to press, to suck out, suckle' (DM 277).

Arb. mașsa 'humer, boire petit à petit en humant; sucer' (BK II 1114).

Tgr. mașiṣ ‘juice, sap (of plants)’ (LH 145).

Amh. mättäțä 'to suck, suck clean, e.g. finer of sauce, to suckle slowly (baby); to soak up, blot up' (K 360).

Har. mätäta ‘absorb liquid, suck up’ (LHar. 115).

Gur. Zwy. mätätä, Msq. Gog. Sod. mätțätä 'absorb liquids, suck’ (LGur. 439).

Mhr. məṣ / yəmṣáwṣ / yəmṣāṣ 'to suck' (JM 272).

Hrs. meṣ / yemṣáws / yemṣāṣ 'to suck' (JH 91).

Jib. miṣs / yəmṣés / yúmmuṣ 'to suck' (JJ 175).

Soq. mṣs 'lécher', šímṣaș 'qui suce' (LS 249).

See further LHar. 115 (Har., Tna., Arb., Hbr.), LGur. 439 (Gur., Arb., Hbr., Tna., Amh., Har.).

5. $m \bar{a}$ ləh 'seasoned with salt, salty, which is tasty' (LGz. 343, LLA 146), malləha 'season with salt, make tasty' (LGz. 343), tamalha, tamalləha passive, 'be salty' (ibid., LLA 146), məlh 'salt, taste, savor, intellect, insight, knowledge' (LGz. 343), 'sapor, judicium, scientia' (LLA 146).

$m a \bar{l}$ oh 'salty' is quoted by Dillmann with only one example of usage, in a genetive construction băhra māloh 'sea of the salty' (ibid.). Obviously, the adjective is rarely used (and probably was formed under the influence of Arb. $m a \bar{l}$ lih-, see below). However, the root itself is well attested, its association with the object 'salt' is clear (although no noun 'salt' is attested among derivatives of this root: the common word for salt in Geez, as in other Ethiosemi-

${ }^{4}$ For a parallel semantic development s. I.7, PS *mtk.

${ }^{5}$ Note that Leslau quotes various spellings of the word (such as malh, molh $\bar{a}$, molh) whereas LLA has molh $\bar{a}$, although in the Dillmann's edition of Deuteronomy the variant molh is used (DiLlmann 1853:376). 
tic languages, is dew, see LGz. 565), and in most of passages dew 'salt' is added as a complement of the verb, e. g., $k^{w}$ ollu ba-sew yətmallăh (LLA 146) 'everything is salted with salt'. One should note the doubtlessly positive connotations of the root, so that metaphorically it can even refer to a saint: hallo yəwaddə? Pəm-zātti bəPəsit həțata șew yətmallāh bottu $k^{w}$ əllu Sālam (Guidi 1909:263) 'from this woman a grain of salt will emerge with which the whole world will be salted'. Another evidence of the positive connotations of the root $\mathrm{mlh}$ is its derivative molh 'intellect, insight', which, according to LLA 146, is an antonym of loshat 'insipidness, dullness' (see I.1). It is used in Deut. 32:28: Pəsma həzb həgulāna məkr Pəmmuntu wa-Palbomu məlha wahaymānota 'because they are people deprived of understanding, and they have no insight and no faith'; the same passage with slight modifications (?əsma həzb həgulāna məkr ?әmmuntu wa-?albomu məlh wa-?i-hāymanot) is quoted in Grébaut 74. The presence in Arabic of an exact semantic and phonetic correspondence milh- (see below) brings into question the possibility of a borrowing from Arabic; one should at least suspect an Arabic influence, causing this particular semantic shift.

The root goes back to PS * $m$ Vlh- 'salt':

Hbr. melah 'Salz' (HALAT 557).

Pho. mlh 'salt worker' (T 179).

Bib. molah 'salt' (HALOT 1916).

Old. Off. Palm. mlh 'salt' (HJ 632).

Jud. melah, molah, milhāa 'salt' (Ja. 788).

Syr. melhā 'sal' (Brock. 390).

JPA mlh 'salt' (Sokoloff 309).

Sam. mlh 'salt' (Tal 468).

Mnd. MHL 'to salt' (DM 260), mihla 'salt' (ibid. 266) (with metathesis). Ugr. mlht 'salt; salted (fish/meat)' (DUL 549).

This sequence of consonants is attested both as noun (e. g., alp $\underline{t} t \mathrm{~m} \mathrm{kbd}$ $m l h t$ 'one thousand and sixty shekels of salt' 4.344:22; $w$ hms $w$ mlht 'and vinegar and salt' 1.175:6, ibid. 549) and as an adjective (uz mrat mlht 'a fattened goose, salted' 4.247:20, ibid.). The noun $m l h$ is usually interpreted as 'beauty' (ibid. 548) and derived from the root $\mathrm{mlh}$ 'to be salty', the semantic shift being explained by the well-known positive connotations of the root, as well as by semantic parallels in Arabic mlh and in Akkadian $t \bar{a} b t u$ (see below). However, in case of Ugaritic $m l h$, the meaning 'beauty' is far from evident, the only passage quoted by DUL 448 being KTU 4.17:17: mlh krn bn $d($ ?) 'the beauty(?) of the horns of the son of D'. It seems that in this fragmentary and unclear context the interpretation of $m l h$ as having the original meaning 'salt' is at least not more improbable than that suggested in DUL.

Arb. milh- 'sel', malaha 'saler suffisamment' (BK II 1144), malīh- 'salé, qui a un goût salé (eau, etc.); salé (poisson, etc)' (ibid. 1145). 
The Arabic root has strong positive connotations, expressed by such derivatives as maluha 'être beau de visage; être beau ou bon (se dit de toute chose)' (ibid. 1144), mulāh- 'beau (de visage)', Pamlah - '... plus beau; meilleur, le meilleur' (ibid. 1145), malīh- 'beau (de visage); beau jeune homme, bel homme; bon' (ibid., Lane 2733), cf. also zayn-u l-milāh-i 'ornement des beaux', an epithet of Mohammed (BK II 1145). Two other meanings associated with the concept 'salt' should be noted here, namely, 'understanding' (milh- 'sel; l'esprit, le piquant (d'un discours, d'une oeuvre littéraire); science; les savants', ibid. 1144, Lane 2732), and 'irony' (malhat'bon mot ou anecdote plaisante; facétie', BK II 1144, mulhat- 'a goodly, beautiful, pretty, or facetious, story; a bon-mot', Lane 2733).

Mhr. amōloh 'to salt (food)' (JM 266).

Hrs. melhāt 'salt' (JH 88).

Jib. mílah 'to salt', mídhót 'salt' (JJ 171).

Soq. mílho 'sel' (LS 243).

A possible cognate in Akkadian is mil?u '(a mineral)' SB, NA (CAD MII 69), 'Salpeter' (AHw. 653). Obviously von Soden's translation is based on his comparison of this root to Proto-Semitic * $m$ Vlh-; however, since no synchronic Akkadian evidence contradicts this interpretation, it can be provisionally accepted as a not improbable one.

Tgr. malha 'to turn sour, to ferment; to salt' (LH 107) presents a shift of meaning allowing various explanations. The semantic development could be based on the designation of the process of preparing food: 'to be salted, to be submitted to a process involving addition of salt' $>$ 'to be fermented, to be submitted to a process involving addition of fermenting substances'. Another explanation would suggest a generalization of taste meaning 'salty, having sharp unpleasant taste' $>$ 'having unpleasant taste, salty or sour'. The first option is, however, to be preferred, since the Tigre dictionary only attests to a verbal meaning.

In view of the Arabic figurative meaning 'to be good', one can compare this root to Harari verb mälaha 'choose, select, prefer by choosing', muluh 'chosen, better' (LHar. 107). It is unclear, however, whether the Harari lexeme is an independent development or a borrowing from Arabic.

In Amharic, we find only a Geez loanword mälähe, mälh 'salt' (K 143).

In view of semantic shift 'salty' > 'good, beautiful', attested in Arabic and (less probably) in Ugaritic, one cannot help mentioning Akkadian term tăbtu, attested with semantics 'goodness' and 'salt': țābtu 'Gutes, Güte, Wohltat' Babyl., NA, lex. (AHw. 1377); țābtu 'Salz' OB, OA, NB, MA, NA, SB, LB, Nuzi, lex. (ibid.). Both meanings are obviously derived from verb tābu 'to have pleasant taste; to be good' ${ }^{6}$ which is widely used to express the idea

${ }^{6}$ The Akkadian root goes back to well-known PS *tyb 'to have pleasant taste; to be good': Ugr. $t b$ 'good, pure, sterling; sweet, generous; pleasant, dulcet' (DUL 886); Hbr. tồb 'gut' (HALAT 355); Syr. tāàb 'bonus' (Brock. 269); Mnd. TAB, TUB 'to 
of agreeable taste, being applied to such objects as water (according to von Soden, denoting sweet water, river water as opposed to salty, sea water: $m \hat{u}$ tâmti mû ța-bu-tú, ibid. 1378), wine, beer, oil, bread, fruits, sugar cane (ibid. 1378). The meaning 'salt' is probably developed from a more general meaning 'that which has a pleasant taste' or 'that which provides a pleasant taste'; the concept of salt as a prototype of pleasant taste is widespread in the languages of the world (cf. Gruntov, ms.).

See further Brock. 390 (Syr., Arm., Hbr., Arb., Akk.), DM 266 (Mnd., Syr., Hbr., Arb., Akk.), BDB 571 (Hbr., Arb., Arm.).

\section{6. marir 'bitter', marara 'be bitter' (LGz. 360, LLA 165).}

The root is well attested in Geez, both in its primary taste meaning (marira kona mes, Jes. 24:9, see LLA 165, 'the honey became bitter'; wa-sə?ənu satya ?әmmərā Pəsma marir māyu, Ex. 15:23, 'and they could not drink from Marah, because its water is bitter') and in figurative meanings: 'sorrowful, grievous' (LGz. 360, e. g. wa-ta Saggaśu mota marira ba-Pənta mangəśta samāyāt, Fries 1892 45, 64, 'they have experienced a bitter death for the sake

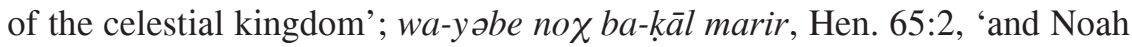

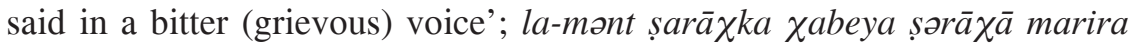
wa-bəkaya, Hen. 65:5, 'why did you cry out to me with such bitter crying and weeping?'; wa-marira hazana yātekkəzəwwo wa-yāmanazzəzəwwo, Sir. $25: 18$, 'they are saddening him and oppressing him by bitter grief'; marira yəbakkəyu, Jes. 33:7, see LLA 166, 'they are crying bitterly'; yəx eyyəs mawit Pəm-marār həywat, Sir. 30:17, 'to die is better than the bitter life'); 'embittered, ferocious' (LGz. 360, e. g., həzb marirān, Hab. 1:6, see LLA 165, 'the bitter (cruel) people'; marirāna nafs, Jud. 18:25, see LLA 165, 'the bitter (cruel) of soul').

The term goes back to the well-known Proto-Semitic root* $m r r$ 'to be bitter':

Tna. märärä 'become bitter, sour' (KT 361), märrir 'bitter, sour, pungent' (ibid. 362).

Tgr. marra 'to be bitter, to be bad', marir 'bitter; a bitter beverage; spice herbs' (LH 113).

Amh. märara 'bitter, sour' (K 178), märrärä 'to taste bitter, be sour or acid (green fruit); to be distasteful, unpleasant' (ibid. 177).

Har. märära 'be bitter', murur 'bitter' (LHar. 111).

Gaf. (at)mirrärä 'irriter, mettre en colère' (LGaf. 217).

Arg. märrära 'be bitter' (LArg. 213).

Gur. Cha. Eža Muh. märara, Msq. Gog. märara kəb, Enm. Gyt. marara, End. marārä 'fresh butter preserved for a long time by periodically adding spices' (LGur. 423).

be well, good, wholesome" (DM 171); Arb. țāba 'être bon; être agréable, d'un goût ou d'une odeur agréable' (BK II 126, Lane 1900); Mhr. ţəyub ‘to enjoy’ (JM 413), etc. 
Hbr. mārōr 'bitter' (HALAT 603), pB. mārar 'to be bitter' (Ja. 847), mərīrā 'bitterness, trnsf. sin' (ibid. 843).

Off. $m r r$ 'to be bitter', $m r r$ 'bitter', $m r r w$ 'bitterness' (HJ 696).

Jud. mərar 'to be bitter' (Ja. 847), mārīir, mārīirā 'bitter', mərīrū, mərīinutā 'bitterness; curse' (ibid. 843).

Syr. mar 'acerbus fuit', marrirā 'amarus' (Brock. 400), marrī 'amarum reddidit; amarus fuit' (ibid. 402).

Sam. mrr 'bitterness', mrwr 'bitter' (Tal 488), mryr 'bitter' (ibid. 489).

JPA $m r r$ 'bitterness, bitter herb', mrr 'to make bitter' (Sokoloff 332).

Mnd. mura 'bitterness' (DM 262f.), mrira 'bitter', mrirta 'bitterness' (ibid. 278), $M R R$ 'to be(come) bitter, afflict; to be spoiled' (ibid. 279).

Akk. marāru 'to be bitter; (with kakku) to prevail (said of military force)' OB, SB, NB (CAD MI 267), 'bitter werden, sein' (AHw. 609), marru 'bitter, brackish, biting' Mari, MB, SB, Bogh. (CAD MI 286), 'bitter' (AHw. 612).

Arb. marra 'être amer; dire des chose amères, désagréables' (BK II 1083), murr- 'amer' (ibid. 1084).

Mhr. mor 'bitter' (JM 268).

Hrs. mer 'bitter' (JH 89).

Soq. Pímrir 'rendre amer' (LS 251).

For this Proto-Semitic root, an excellent semantic analysis has been given by D. Pardee (1978). However, it is necessary to quote the attested meanings and relevant passages in the present contribution once again. One can summarize the meaning shifts attested in this root as follows:

a. Semantic shift within the lexical field of taste: broadening of the meaning 'bitter' > 'bitter, sour' (cf. Tna. märrir 'bitter, sour, pungent', KT 362; Amh. märara 'bitter, sour', K 178).

b. A (synesthetic?) shift 'bitter, causing unpleasant taste sensation' > 'causing unpleasant (tactile?) sensation' (applied to sun in Tna. märärä 'to be pungent; to be burning hot (sun)', KT 361; to wind in Akkadian, šāru marru

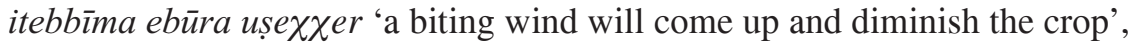
CAD MI 287). This seems to be a synesthetic development from taste to tactile terms, see II.3. However, both examples can be reinterpreted as 'bitter' > 'cruel' (see below), both wind and sun being able to be personified.

c. Semantic shift provoked by a general metaphor 'to taste' > 'to experience' (see II.4): 'bitter' > 'hard, difficult to bear, harsh' (cf. Amh. nuro märräräw 'life was unpleasant/bitter for him', K 177, märara mot 'bitter death', märara nägär 'grievous matter, affair', ibid. 178; Jud. mērūr 'embittering, hard labor', Ja. 779; Sam. mrwr 'bitter': ḥbws mrwr ḥbwsh dh skh 'a bitter jail is the jail of the darkness', Tal 488; Mnd. mura 'bitterness': ulinšia mura nihuilun 'and there will be bitterness for women', DM 262f.; for the application of the root in Syriac to describe torture, prison, difficult time, see Pardee 1978:269f.; see also a context combining both direct and metaphorical application of the root in Official Aramaic: timt $? p$ z $\{r r t ?$ mrrt? 
$w[t$ Ifm $]$ ? hsyn wl? PYyty zy $[\mathrm{m}]$ ryr $m n$ Snwh, Ahiq 188, 'I have tasted the bitter medlar and the taste is strong, but there is nothing more bitter than poverty', HJ 696; cf. also Arb. ؟ǐš-un murr-un 'a bitter life', marrat Salayhi Pamrār-un 'afflictions or calamities came upon him', Lane 2701; for Geez, see above; a verbal realization of the same metaphor is causative 'to make bitter' > 'to make difficult to bear, harsh': Hbr. wayəmārərû ?et-hayyēhem baৎăbō $\bar{a} k \bar{a} \bar{s} \bar{a}$ 'and they embittered their lives by hard labor', Ex. 1:14; Sam. myrr 'to embitter': whbt mrn rwh lyṣhk wlrbkh 'they made life bitter for Isaac and Rebecca', Tal 488).

d. Application of the term to describe mental qualities and emotions (see II.5):

1) 'bitter' > 'grievous' (cf. Tna. märärä 'to be stricken with sadness, melancholy; to be sorry, grieve, be sad; to complain, grumble, gripe', e. g., in Pamrirom bäkäyula 'they cried bitterly for her', KT 361f.; Tgr. marra 'to be sulky', LH 113; Amh. morr alä 'to be or become deeply grieved, very sad', K 178; Hbr. Pămārēer babbek̄̄ 'I weep bitterly', Jes. 22:4; Syr. mar 'dolui', Brock. 400; Mnd. MRR 'be grieved; to be spoiled', DM 279; Jud. morar 'to grieve, mourn', Ja. 847, mārìr, mārìrā 'embittered, grieving', ibid. 843; Sam. mryr 'bitter': wșb șbih rbh wmryrh 'he cried out with a great and bitter cry', Tal 489; cf. also Gur. Sel. märärä-, Wol. tämärärä-, tämarärä 'feel sorry for someone', LGur. 423; for Geez, see above);

2) 'bitter' > 'angry, violent, cruel' (cf. Tna. märrir 'one who only has bad words for others, crabbed, shrewish, cantankerous; inclement, harsh, severe, virulent', KT 362; Amh. märrärä 'to be angry, vexed, upset', yämärrärä 'violent', K 177; Arg. asmerrära 'irritate', LArg. 213; Gur. Sel. Wol. Zwy. märärä, Muh. Msq. Gog. Sod. märrärä, Cha. Enm. Gyt. mänärä, Eža männärä, End. mennärä 'be bitter, be angry', Gog. Sod. marrätam, Muh. mərrätäňn̆ä 'angry, furious, short-tempered', LGur. 423; Syr. marīr napš̄a 'malignus', Brock. 400, cf. also the passage illustrating the meaning 'terrible, cruel' quoted in Pardee 1978:267f.; Sam. $m r r$ 'quarrel', Tal 488; for Gafat, see above; cf. also the following context in Akkadian: kišaa martu mar-ratu-u-ni [attunu] SAL.MEŠ- $k u-n u$ DUMU.MEŠ- $k u-n u$ DUMU.SAL.MEŠ-

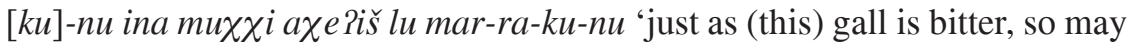
you, your wives, sons and daughters be bitter toward one another', CAD MI 267, and the application of the same Akkadian term to the weapon: kakki DN $u$ RN marrūtim ukallamka 'I will show you the destructive weapons of Adad', CAD MI 287; for Geez, see above);

3 ) the application of the root to qualify human speech probably unites synesthetic development 'taste' > 'sound' (see II.3) and metaphoric usage to describe human emotions: 'bitter' $>$ 'unpleasant, pungeant, sharp (words, etc.)' (cf. Tna. märrir 'biting, sharp (words), acrimonious (debate)', märrir kalat 'harsh words', mälhasu (?afu) märrir zə-konä säb 'evil-tongued fellow, harsh', KT 362; cf. Arb. ?al-ḥakk-u murr-un 'la vérité est amère (à dire)', 
BK II 1084; mā Pamarra wa-mā Pahlá 'he said not (or he did not) a bitter thing, and he said not (or he did not), a sweet thing', Lane 2700; cf. also Hbr. mərōrōt 'bittere Erfahrungen', HALAT 603, in Job 13:26, as a complement to verb 'write': kī-tiktōb Sālay mərōrōt 'for you write bitter things against me').

Besides, the root $m r r$ is attested as referring to strength or courage in Ugaritic, Arabic and Modern South Arabian:

Ugr. $m-r-(r) \mathrm{G}$ 'to strengthen', $\mathrm{N}$ 'to be strengthened' (DUL 577f.).

Arb. marīr- 'fort, robuste, solide (homme); résolution ferme et inébranlable' (BK II 1084, Lane 2701).

Mhr. amrīr / yamrīron / yamrīr / yammrīron 'to give so. courage, embolden' (JM 268).

Hrs. merrét '....strength' (JH 89).

Jib. emrér / ys̃amrér / yš́mmor 'to be emboldened', merrót 'courage' (JJ 173).

Note also the usage of Tgr. marir 'bitter' to describe a horse hoof: 'hard, powerful' (LH 113), possibly also Amh. amärrärä 'to make a difficult and final decision' (K 177).

The usage of the Arabic and Tigre terms has been discussed in Pardee (1978:270-274). Pardee's conclusion is that in both cases the meaning 'strong' is attested, in Tigre probably under Arabic influence. However, one cannot suspect a calque from Arabic in the case of Modern South Arabian, since, at least in the contexts quoted by Pardee for Arabic, no exact semantic identity is present. Moreover, the meaning 'to give courage, embolden' in Mehri and Jibbali corresponds to the meaning usually reconstructed for Ugaritic (where the verb $m r(r)$ is paralleled by $b r k$, 'bless', Pardee 1978:250f.). It seems that, contrary to Pardee, the Modern South Arabian evidence, as well as that of Arabic and (probably) Tigre, does favour the reconstruction of a verb $\mathrm{mrr}$ 'to strenghthen' in Ugaritic.

It is tempting to consider these terms as eventually developed from the meaning 'violent' (derived, in its turn, from 'bitter', see above). However, this semantic shift would be the only one involving the loss of negative connotations of the root, and, as Pardee rightly observes (1978:275), would present a typologically unlikely semantic development. A contamination of * $m r r$ with *mr? 'man' > 'manly, couragious' is not improbable.

See further LGz. 360 (Gez., Arb., Mhr., Hbr., Arm., Syr., Mnd., Akk., Tna., Tgr., Amh., Arg., Har., Gur.), LS 251 (Soq., Arb., Mhr.), LGur. 423 (Gur., Arb., Hbr., Gez., Tna., Tgr., Amh., Arg., Har.).

Note also PS *mi/ar(r)-at-, *mirār-at- 'gall, gall-bladder' (SED No. 188). While the authors of the dictionary tend to regard the two terms as belonging to homonymous roots, later connected through contamination, such a coincidence in semantics seems highly improbable; a derivation of one from another may be safely reconstructed on the Proto-Semitic level (presumably, from the taste term 'bitter' a name for its prototype, 'gall-bladder', was derived). Some of the reflexes of the noun 'gall, gall-bladder' have meaning 
'poison' (Hbr.pB, Off., Warka, Dem., Syr., Mnd., see SED No. 188); this semantic development is based on the conception of bitter taste as a token of poisonous qualities (one can probably regard the bitter taste as a prototypical taste of poison).

\section{7. motuk 'sweet', moțat 'sweetness' (LGz. 373, LLA 221).}

This root is poorly attested in Geez. Dillmann quotes one passage where the adjective motuk is used in a figurative meaning as a qualifier of light (mətuk bərhān 'sweet light'), and one usage of the noun motkat in Jud. 9:11, where it corresponds to Gr. glukùtés (LLA 221).

In Ethiosemitic languages, the root is widely attested, although with considerable semantic deviations:

Tna. mätäkäa 'to bake the bread used in brewing beer; to dry, dry up, go dry (spring)', mäțäka, mätäkka 'unleavened bread baked for use in making beer; scraps of angēra which are dried and used in making beer' (KT 521f.).

Tgr. maççaka 'to eat up, to end; to revile strongly' (LH 144).

Amh. mätțäkä 'to be or become very thin, water-like (dough, bread); to rise (dabbo-bread), to bake an unleavened cake' (K 355).

Har. miç̌iq āša 'squeeze something so that it squirts' (LHar. 103).

Gur. Wol. (a)mçaçăkä, Sel. amçaçăäkä 'milk a cow without leaving some milk for the calf; pull out completely' (LGur. 389).

The cognates in other Semitic languages demonstrate both the meaning 'to be sweet, of pleasant taste' and 'to taste, try (food, drink), to suck'. Thus, a PS root *mtk 'to taste, to suck; to be sweet, of pleasant taste' can be reconstructed. A phonetic alternation $t>t$ is unproblematic and can be explained through the influence of emphatic $k:^{7}$

Hbr. mtk 'süss sein, werden' (HALAT 619), mātōk 'süss = angenehm' (ibid. 618).

Note that the root was applied to water that became drinkable: ... walo

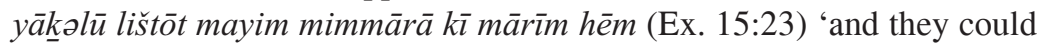
not drink the water of Marah because it was bitter'; ... wayyašlèk Pel-hammayim wa-yyimtəku hammāyim (Ex. 15:25) 'and he threw it into water and it became sweet'.

PB mätak 'to be sweet, palatable', pi. 'to sweeten, season' (Ja. 864), $m \bar{a} t \bar{k} k$ 'sweet, pleasant' (ibid. 860), motīk $\bar{a}$ 'sweet taste; seasoning, relish; sweetmeats, delicacies; sweet drinks' (ibid. 862).

Jud. mətak 'to be sweet, palatable', pa. 'to taste, suck' (Ja. 864), mətīk 'sweet' (ibid. 862).

Syr. mətak 'suxit; sorpsit; inhalavit' (Brock. 410).

JPA mtk 'to suck' (Sokoloff 338).

Sam. mtk 'sweetness', hmtyk 'to make sweet' (Tal 493).

\footnotetext{
${ }^{7}$ A well-known example of such change is root *ktl 'to kill' (Arb. ktl vs. Hbr. kțl).
} 
Akk. matāku 'to become sweet' SB, NA (CAD MI 405), 'süß werden, sein' (AHw. 632), matku 'sweet' from OAkk., OB on (CAD MI 413), 'süß' (AHw. 633).

The root is well attested in Akkadian, its meaning can be illustrated by such passages as kî ša dišpu ma-ti-ku-u-ni damu ša SAL.MEŠ-ku-nu... ina pi-kunu li-im-ti-iq 'just as (this) honey is sweet, so may the blood of your wives (and children) become sweet-tasting in your mouth' (CAD MI 405). The adjective matku is used to describe such objects as pomegranates, dates, almonds, melons, honey, milk, apples, bread (ibid. 413).

Arb. tamattaka 'goûter, essayer le goût de...; savourer quelque chose' (BK II 1123).

Mhr. matk 'sweet', motáwk 'to taste' (JM 273).

Hrs. matk 'sweet' (JH 91).

Jib. mútţok / yəmtétékən / yəmtétók 'to have st. sweet in your mouth to chew; to try, taste st. before swallowing it', mițáyk 'sweet' (JJ 176).

Soq. métok 'sucré' (LS 242).

The semantic deviations of this root in Ethiosemitic languages remain to be explained. The range of meanings attested in this language group comprise such as 'to be sweet' (Gez.), 'to be dry' (Tna.), 'to be non-fermented, unleavened' (Amh., Tna.), 'to squeeze' (Har.), 'to eat up' (Tgr.), 'to milk a cow without leaving milk for a calf' (Gur.). One can suggest various ways of semantic evolution; naturally, the evidence from other Semitic languages should be taken in consideration. Thus, in view of the meaning 'to suck', attested for the root in Judaic Aramaic, Syriac and Jewish Palestinian Aramaic, one should reconstruct the meaning 'to suck' as early as in the ProtoSemitic. This semantics would be hardly related to the concept of sweetness, had it not been for the verbs 'to taste', attested in Arabic, Mehri and Jibbali: the semantic shift 'to taste' > 'to be of pleasant taste, to be sweet' is well attested (see II.2), whereas the meaning change 'to suck' > 'to taste' (or vice versa) can also be easily imagined (the specific semantic developments in Tigre and Gurage go back in all probability to the meaning 'to suck' as well).

Other meanings attested for the reflexes of * $m t k$ in Ethiosemitic languages ('to be dry', 'to be unleavened (bread)', 'to squeeze') should be grouped together, since they correspond exactly to the semantics of reflexes of another PS verb 'to suck', namely, *mṣs (see I.4). Therefore, we are justified in supposing that these meanings are related to each other and can be organized into a chain of semantic evolution. The meanings 'to suck', 'to squeeze' and 'to dry up' are connected through the common component 'to remove liquid' (obviously, Gurage 'to milk a cow without leaving milk for a calf' also belongs here, being derived from any of these meanings). The designation of unleavened dough through the root 'to squeeze, to dry, to suck' can have different explanations. One can argue, for instance, that the 
unleavened dough was perceived as hard and dry, being opposed to the soft leavened dough. However, it should be noted that in Judaic Aramaic the root $m t k$ is used to denote the unfermented drinks, opposed to the fermented ones: hnydr mn htyrwš ?swr bkl myny mtykh 'he who vows abstinence from tirosh, is forbidden all kinds of sweet (unfermented) drinks' (Ja. 862). Either this is a generalization of the meaning 'unleavened (bread)' $>$ 'unfermented (bread, beverage)' (which should suggest that the meaning 'unleavened' was already present on Proto-Semitic level), or both applications to unleavened bread and unfermented beverage should be explained in the context of another semantic development, namely, 'sweet, of pleasant taste' > 'unfermented'. Such usage of the term 'sweet' is provoked by its opposition to 'sour', the process of fermentation being normally associated with the sour taste (see I.2).

See further Brock. 410 (Syr., Jud., Hbr., Arb., Gez., Akk.).

8. kasama, kassama, kaśśama 'season, make tasty', kəssum 'well seasoned, tasty, that has savor', kasm 'seasoning' (LGz. 446, LLA 432).

The root conveys the idea of good taste, being contextually opposed to the root $l s h$ (see I.2) and marked by positive connotations. One should note that in almost all passages quoted by Dillmann the precise taste designated by the root is salty, and the verb is complemented by the prepositional phrase ba-sew 'with the salt': wa-yərassəyani kəśśuma ba-dewa malakot wa-yābrəh wəsta labbəya māxtota təbab (Grohmann 1919: 168) 'let him make me salted with the salt of divinity and let him light in my heart the torch of wisdom'. The meaning 'salty' is probably a secondary development, explained by the fact that the taste of salt was considered the best representative of the good, pleasant taste, cf. a figurative usage of the root $\mathrm{ksm}$, where a comparison with salt is employed to stress its positive connotations: tagśăs tôum wa-zenā kəssum kama șew 'the sweet chastisement and the announcement which is good-tasted as salt' (LLA 432). In the rest of the contexts its meaning is non-

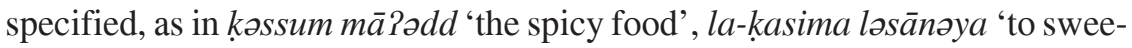
ten (lit. 'to add taste to') my tongue' (ibid.).

The doubtlessly related verb in Amharic, kässämä ('to season, render savory (with salt or spices); to compound, mix or blend together', K 751f.; cf. also kəsəm 'force; pleasing, dignified presence or appearance; taste, flavor of wood, food, dew which may be bitter or sweet depending on the climate and soil', ibid. 752) may be a borrowing from Geez. Cf. also Amh. kassämä 'to smell, to sniff s.th.' (K 752), presenting a synesthetic change from taste to smell.

We find a more reliable cognate in Arabic, where the meaning 'to eat, to choose best pieces of food' is attested: kašama 'manger; manger beaucoup; choisir les meilleurs morceaux, et le manger en laissant les autres' (BK II 744). At the same time, in view of the Arabic meaning, a comparison to Tna. käsämä, demonstrating a rather distant semantic 'to sip nectar (bee), gather 
nectar' (KT 962) becomes more likely; a possible reconstruction of the semantic evolution would be to derive the Geez meaning 'to have good taste' from the meaning 'to taste' (attested as 'to eat; to eat best morsels' in Arabic and as 'to sip' in Tigrinya).

Cf. also Sab. $\mathrm{ks}^{2} m$ '? a vegetable plot' (SD 108).

At the same time, it is difficult to refrain from relating the root in question to the common Ethiosemitic verb *kms 'to taste':

Tna. kämäs ä 'to taste (a dish), take a taste of s.th., to have a bite to eat, a snack' (KT 914); Paḳmäsä 'to give s.o. some bits of food or drink (host to a guest), to cause to taste; to snack, to have a bite to eat', kəmso 'taste; example or sample' (ibid. 915).

Note also further semantic development of the causative verb Paḳmäs ä 'to cause to taste' > 'to let somebody experience s.th.': bätri Pakmisuwo 'he beat him with a stick' (ibid.) (lit. 'he caused him to taste a stick').

Tgr. kamša 'to dip; to take a pinch of snuff; to go to a prostitute for the first time' (LH 237).

Amh. kammäs $\ddot{a}$ 'to taste, take a taste of s.th., fig. to experience (misfortune, etc.), to suffer a beating; to be a mixture of many kinds of soil; to do s.th. first, be first in s.th.' (K 702).

For the meaning 'to experience', cp. such contexts as batr kammäsä 'to receive a beating', nuro kammäsä 'to experience life', yäfitən tor kämmäsä 'to be the first to engage the enemy' (ibid.).

Arg. kämmäsa 'taste' (LArg. 216).

Gur. Cha. Enm. End. Gyt. Sel. Wol. Zwy. kämäsä, Eža Muh. Msq. Gog. Sod. kämmäsä 'taste; have intercourse (euphemism)', Cha. kəmus, Eža kəmmus 'tasty', Muh. kəmša 'a taste of something', Cha. Enm. kəmamäsä, Eža Muh. kəmammäsä, Enm. End. Gyt. täkmamäsä, Eža Muh. täkmammäsä, End. täkwamäsä 'eat a little bit' (LGur. 482).

One wonders whether this root could be related to Har. kèmäsa 'sharpen a pen, pencil or reed, sharpen a point', through the synesthetic transfer of meaning 'tasty, spicy (taste sense)' > 'sharp (tactile sense)' (which would, however, contradict Williams's generalization, see II.3). At the same time, the meaning 'beautiful', also attested in Harari for this root (täkēmäsa 'become slim, become elegant', (a)kōmäsa 'be beautiful', LHar. 126), may be derived from the meaning 'tasty, having good taste' as well (cf. II.6).

See further LGur. 482 (Gur., Tna., Tgr., Amh., Gez.).

9. təSma, ta @ama 'taste, be tasty, be delicious, be savory, be sweet, experience', tôum 'tasty, savory, sweet, pleasant, delicious' (LGz. 582, LLA 1241f.).

The root is widely used and conveys the general idea of pleasant taste, $\mathrm{cf}$. such usages as fot tə̊um (Prov. 17:1) 'delicious morsel', mabāləSət tôum (2 Par. 9:24, see LLA 1242) 'delicious dishes'. Unlike the root ksm (see I.8), 
the root $t$ t $m$ seems to be associated with the sweet taste, and is used to qualify such objects as honey: måār țium (Hez. 3:3, see LLA 1242) 'sweet honey'. Of special interest is its use as an attribute of water, designating drinkable water, cf. such usages as wa-rəPəyat Sazakta māy tôum (Gen. 21:19) 'she saw a well of fresh water'; wa-rakabu nakia māy ț̊um (Gen. 26:19) 'and they found a spring of fresh water'; wa-yətabbəhəwwa la-yə?əti dorho wəsta $m \bar{a} y$ ț̊\{um (Lev. 14:5) 'and they kill this chicken in fresh water'; māy $z a$ təSum marira yəkawwon 'the water which is sweet becomes bitter' (see LLA 1242). Note that the verb təima is used to describe a situation when bitter, brackish water becomes fresh, drinkable: wa-Par?ayo Pəgzi?abher Səda wawadayo wəsta māy wa-țîma māyu (Ex 15:25) 'and God showed him a piece of wood and he threw it into water and the water became good'.

The verb təSma, tåama can also be used, on the one hand, as a predicative

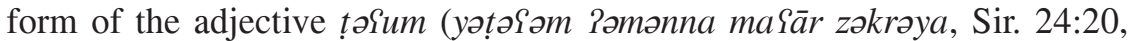
'mentioning me is sweeter than honey') and, on the other hand, as an active verb 'to taste, to try (food, drink)' ( Pi-yəkəl tọima mabləSa, Job 33:20, 'he cannot taste the food').

One should also note the usage of the root in application to sounds, retai-

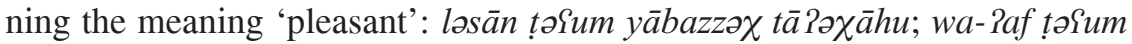

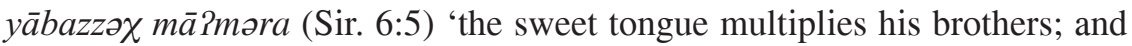
the sweet mouth multiplies the knowledge'; masanko wa-mazmur yəhewwoz $\bar{a}$ la-nafs; wa-Pəmənna kəliehomu ləsān tə̊um (Sir. 40:21) 'the violin and the singing gladden the soul; but the pleasant tongue does better than both of them'; təSum nagar (Job 6:6) 'pleasant speech'; wa-g "əmā kālomu hawāz wa-țofum (Sir. 47:9) 'and the melody of their voice is pleasant and sweet'; təbab la-sami toYum 'the wisdom, pleasant to hear'; təSumāna zenā wa-zəkr 'the pleasant of announcement and commemoration' (LLA 1242).

Note also the figurative usage of the verb toima in the sense 'to experi-

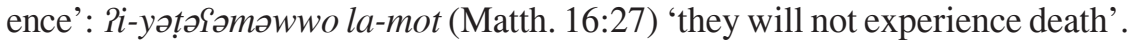

The cognates in Ethiosemitic demonstrate both the meaning 'to have pleasant taste' and 'to taste, to find out the taste of s.th.':

Tna. țäßamä 'to taste, try (a dish), to take a sip (of beer); to be sweet, savory, to be tasty, to be pleasing, pleasant, e. g., speech, to be good, convenient, suitable, comfortable' (KT 2472), ţ̧um 'sweet, good, tasty, savory, delicious, appetizing, luscious, succulent, toothsome; gentle, amiable, cheerful, pleasing, agreeable, mellifluous; livable, cozy, fig. good, kind, gentle; comfortable, convenient' (ibid. 2473).

One should note a peculiar semantic development in Tigrinya: 'to have taste of s.th.' > 'to seem, to be like s.th.'. Consider the following usage: «bäyyänä yətə९̊m» bälä däbäsay Panfät nayti Pawyāt fäșimu səlläzäy täräd?o '«It sounds like Bäyyänä [lit. 'it has the taste of Bäyyänä']» said Däbäsay since he did not realize the direction the cries [were coming from]' (ibid. 2472). Cf. similar metaphors involving the visionary or acoustic per- 
ception: English look (it looks like rain), sound (it sounds a good idea); German aussehen (ihre Reise sah nach Flucht aus).

Tgr. ta Aama 'to be sweet, savoury; to taste', təSum 'sweet, savoury' (LH 619).

Amh. tamä 'to be tasty, taste pleasant, be of good taste, be savory, to taste (vt.), take a taste of; to be deeply in love; to satisfy, content (vt.)', yätamä 'savory, tasty, flavorful' (K 2097).

Har. țāma, țema 'taste good, be tasty, have flavor, taste', yițīmzāl 'sweet', tima 'taste, pleasure' (LHar. 154).

Gaf. çamä 'avoir bon goût' (LGaf. 193).

Arg. țähama 'taste good, flavor' (LArg. 223).

Gur. End. țāmä, Msq. țamä, Cha. Eža Muh. Msq. tamä, Gyt. tāmä, Muh.

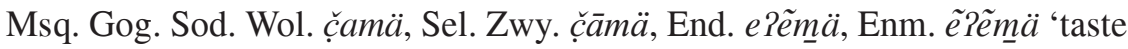
good, have flavor, be sweet, be dear, be expensive' (LGur. 619).

Another set of Gurage lexemes with similar semantics demonstrate a metathesis: tamä > mäta, possibly influenced by another taste term, *mș̣̂s (see I.4): Gur. Cha. (a)mätta, Gyt. amä̈tā, Enm. amäạtā, Eža amäțta 'taste good', Cha. amțța, Enm. Gyt. amțtâa, Eža Muh. amțatța 'find out the taste of food or drink' (LGur. 437).

The root goes back to the well-known PS *ţm 'to taste, to try (food)'

Hbr. $t 9 m$ 'Geschmack v. Speisen versuchen, kosten; Speise geniessen, essen', țåam 'Geschmack (v. Speise)' (HALAT 361).

Off. $t$ im 'to taste' (HJ 426f.), Palm. t Smh 'victuals' (ibid. 428).

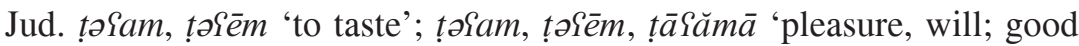
cheer' (Ja. 543), maṭ Yămāa 'savory, refreshing' (ibid. 769).

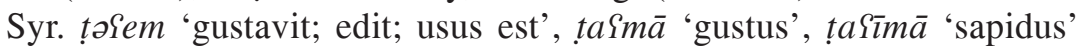
(Brock. 283).

JPA $t$ Sm 'to taste, eat', $t$ Sm 'taste' (Sokoloff 228).

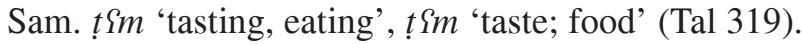

Mnd. TAM 'to taste, try, test, examine, eat', tama 'taste, flavour, savour, quality; appreciation, pleasure, will' (DM 174).

Arb. țaSima 'manger, avaler, prendre quelque chose; goûter, deguster', tataYYama 'goûter, déguster; savourer' (BK II 83), țåm- 'goût, saveur; appétit' (ibid. 84).

Sab. $t \uparrow m$ 'give enjoyment of crops' (SD 152).

Mhr. ţim: țām / yəțōm / yətáymon 'to eat, taste, try (food)', tôēem 'food' (JM 405).

Hrs. țim: țām / yețom 'to taste, have taste of' (JH 128).

Jib. tạám / yṭơúm / yəṭ̂́m 'to eat, taste', țåmún 'tasty; tasted' (JJ 273).

Soq. tá̧am 'manger, goûter' (LS 206).

Although the meaning 'have a pleasant taste' occurs in many reflexes of the root (Gez., Tna., Amh., Har., Gaf., Arg., Gur., Jud., Jib.), one can doubt whether this semantics should be reconstructed on the Proto-Semitic level; it 
may be that the semantic shift 'to taste' > 'to have pleasant taste' (see II.2) has taken place independently in Ethiosemitic languages, Judaic Aramaic and Jibbali.

One should note such semantic shifts as 'to taste, to try the taste of food/ drink' > 'to experience s.th., to learn smth. through experience' (see II.4; cf. Hbr. $t$ 乌m 'durch Erfahrung spüren, merken, lernen', HALAT 361: ța९ămū $\bar{u}-$

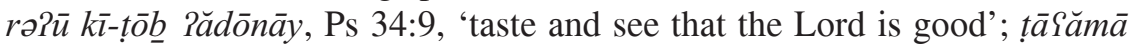
$k \bar{l}-t+\bar{b} \underline{b}$ sahrāh , Prov. 31:18, 'she tasted that her merchandise is good'; $\mathrm{pB}$. țā Sam 'to examine, to taste, test, try, experience', Ja. 543; Bib. ţim (pa.) 'to

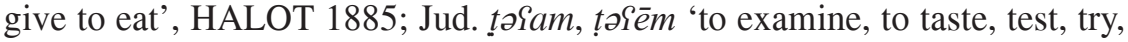
experience', Ja. 543; Mnd. TAM 'appreciate, perceive, discern, experience, savour': tama d-muta lataimin 'they do not taste the taste of death', DM 174; Syr. təYem 'percepit, cognovit', Brock. 283; cf. also Gez. above) and 'taste, sense of taste' > 'judgment, perception, understanding' (see II.5; cf. Hbr. ta9am 'Geschmack (v. Speise); Empfindung, Verstand', HALAT 361; pB. țåam 'sense, wisdom, sound reasoning', Ja. 543; Bib. ţ̊९em 'understanding,

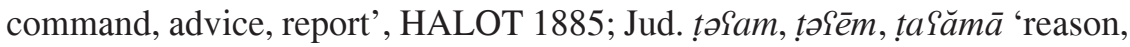
argument, sense', Ja. 543; JPA $t$ t $m$ 'reason, reasoning', Sokoloff 228; Sam. tIm 'sense': t Imh dsbth brkn t Imh d?rhwth mkrth 'the sense of the Sabbath lies in the blessings, the sense of the Torah lies in the reading', Tal 319; Mnd. tama 'judgement, perception, discrimination', DM 174; Syr. țaSmā 'pruden-

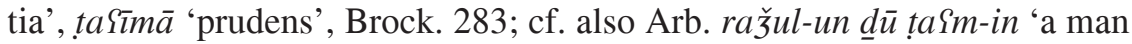
possessing intelligence, and prudence, or discretion', Lane 1854). It seems that the semantic development belongs to the Proto-Semitic level, so that in some languages the original meaning 'to taste' was entirely lost: Off., Nab. ţ $9 m$ 'order; decision, resolution; authority; matter, affair' (HJ 427), Akk. tēmu 'Planungsfähigkeit, Entschluß(kraft); Verstand; Anweisung, Bescheid' OB, NB, NA, MB, OA (AHw. 1385).

See further AHw. 1385 (Akk., Hbr., Arm.), LHar. 154 (Har., Arb., Gez., Tna., Tgr., Amh., Arg., Gaf., Gur.), LGaf. 193 (Gaf., Arb., Gez., Tna., Tgr., Amh., Arg., Har., Gur.), LGur. 619 (Gur., Arb., Hbr., Gez., Tna., Tgr., Amh., Har., Gaf., Arg.), LGz. 582 (Gez., Arb., ESA, Jib., Hbr., Arm., Mnd., Akk., Tna., Tgr., Amh., Har., Gur., Gaf., Arg.), LS 206 (Soq., Mhr., Arb., Hbr., Syr., Akk., Gez.).

\section{The semantic Changes involving the taste names that have been OBSERVED IN THE CONSIDERED MATERIAL}

\section{The derivation of taste names from names of prototypes and vice versa.}

The following taste prototypes have been found out in the course of the investigation: 'honey' > 'sweet' (cf. Gez. maSarSir 'sweet' and Akk. dašpu 'sweet', see I.3), 'salt' > 'salty' (see PS *mlh, I.5). 
The reverse process is also attested: 'sour' > 'vinegar' (cf. Tna. mäṣiṣ 'sour; vinegar', Amh. mäṣaṣa 'vinegar' < mäṣiṣ 'sour', see I.4); 'sour' > 'lemon' (cf. Amh. mäșașa 'lemon' < mäșiș 'sour', see I.4).

\section{Derivation of taste terms from verbs denoting actions or processes and vice versa.}

The most common type of derivation is a formation of a taste name from a root primarily meaning 'to taste, try (food, drink)'. The semantic change taking place in the roots $\mathrm{kms}$ (see I.8) and $\operatorname{tm} \Upsilon$ (see I.9) can be generalized as 'to taste, try (food, drink)' > 'to have good, pleasant taste' (cf. also PS *mtk 'to taste, to suck; to be sweet, of pleasant taste', see I.7).

Taste names can also be derived from verbs that denote various processes associated with acquiring a specific taste. Thus, sour taste may be associated with the process of fermenting (cf. Gez. bh? 'to ferment; to be sour', see I.1; cf. also Gruntov, ms.) or with the process of rotting, decaying (cf. Tna. mäṣiș 'sour', mäççäặä 'to go bad (food)' and mäçäç bälä 'to become moldy', see I.4).

\section{The synesthetic changes.}

In his research on synesthetic semantic changes, Williams postulates that the only sensory lexemes that can switch their meaning to taste are touchwords. At the same time, according to his investigation, «taste-words do not transfer back to tactile experience or forward to dimension or color, but only to smell (sour smells) and sounds (dulcet music)» (Williams 1976:463f.). The present study confirmed the frequent change from taste to sound mean-

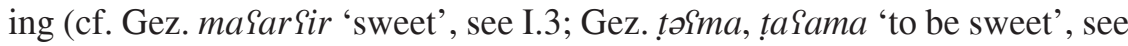
I.9). At the same time, very little direct evidence on applicability of tastewords to smells has been elicited (one possible example is Amh. kassämä 'to smell' < kässämä 'to taste', see I.8). Neither did the Geez vocabulary present an example of touch $>$ taste semantic change. Rather, we have several contradictory examples, e. g., Arb. mdd 'to be sour; to be pungeant, to burn' (see I.4); PS *mrr 'to be bitter', the reflex of which in Tigrinya can be applied to sun in the meaning 'to be pungent; to be burning hot (sun)', in Akkadian to wind 'biting, sharp', and in Tigre can be used to describe a hard horse hoof (see I.6). Obviously, all these contexts involve the touch experience rather than any other sensory experience and would suggest a synesthetic development of a taste term into various touch terms ('hot', 'sharp', 'hard'). One has to admit, however, that such applications are poorly attested and may be explained through an intermediary emotional meaning. Another possible contradiction is Har. kēmäsa 'to sharpen', which may go back to Ethiosemitic root * kms 'to taste' (see I.8).

\section{The changes suggested by metaphor 'to taste, to try (food, drink)' $>$ 'to experience s.th.'.}

The generalization into the meaning 'to experience s.th.' is a well-attested semantic shift for the verbs originally meaning 'to taste, to try (food, drink)' 
(cf. Tna. 2aǩmäsä 'to cause somebody taste s.th.; to cause somebody experience s.th.', Amh. kämmäsä 'to taste; to experience', see I.8; cf. also PS *t .m 'to taste; to experience, to learn by expierience', see I.9). A particular case of this development of meaning is 'to taste' $>$ 'to have a sexual experience' (cf. Tgr. kamša 'to go to a prostitute for the first time' < 'to taste', Gur. kämmäsä 'taste; have intercourse (euphemism)', see I.8; this semantic change is, on the other hand, related to a wide-spread metaphor 'tasty food' $>$ 'attractive woman', see Razuvaev 2004:47).

The metaphor 'to taste, to try (food, drink)' > 'to experience s. th.' provokes a number of other semantic shifts. Various taste adjectives are widely used to describe various events of life, naturally the pleasant tastes describing happy events (cf. Tna. tə\{um 'having pleasant taste; pleasant, agreeable, comfortable', see I.9) and the unpleasant ones being associated with calamities and disasters (cf. PS * $m r r$ 'to be bitter' > 'to be hard, difficult to bear, harsh', see I.6). The life itself is often described in taste terminology, e. g., as bitter (see I.6.c).

\section{The semantic changes involving transfer of a taste term into lexical field of mental qualities or of emotions.}

General verbs 'to taste, try (food, drink)' can derive such meanings as 'judgment, perception, understanding' (cf. reflexes of PS *tim with meanings 'taste' and 'judgment, understanding', see I.9). Probably this semantic shift is suggested by metaphor 'to taste s.th.' > 'to experience, learn s.th.', see II.4. For a similar semantic development, cf. Latin sapere 'to taste, savour' > 'to know, be wise' (Viberg 1984:158).

The pleasant tastes are employed to characterize positive emotions or mental qualities (cf. Gez. tə⿱亠䒑十a, tåama 'to be sweet; to be pleasant', see I.9), and the «bad» tastes describe the negative ones (cf. Gez. madid 'sour; angry', Tna. mäsis 'sour; sour-tempered', see I.4; for the shift 'to be bitter' > 'to be grievous' and 'to be bitter' > 'to be angry' in the PS root *mrr, see I.6.d; rather unexpected meaning shift 'to be bitter' > 'to be brave, courageous, strong' is also, however, attested for the latter term, see I.6). The terms for salty taste usually have positive connotations, and are often employed to decribe a high degree of intelligence (cf. Gez. malh 'understanding' < mlh 'to be salty', Arb. milh- 'salt; knowledge', see I.5), frequently being associated with sense of humor (cf. Arb. mulhat-, malhat- 'a bon-mot' < mlh 'to be salty', see I.5; cf. also Gruntov, ms.). At the same time, the semantic shift 'sour taste' > 'irony' is also attested (Tna. məșsät 'sourness; irony, sarcasm', see I.4). The opposite meaning 'to lack understanding' can be expressed by a root meaning 'to be tasteless' (see Gez. lsh, I.2).

\section{The generalizations and specific developments of meaning.}

a. 'to be tasteless' > 'to be ineffective, lacking s.th.' (Gez. lsh, see I.2);

b. 'to spit' > 'to have taste of saliva, to be tasteless' (Gez. lsh, PS *tpl, see I.2);

c. 'to be sour' > 'to hurt, to cause pain' (cf. Arb. mdd 'to be sour; to hurt', see I.4); 
d. 'to be sour, to ferment' - 'to become thick, to dry up' (Amh. bokka 'to ferment, to turn sour; to thicken', see I.1; Amh. mätṭätä 'to ferment, to turn sour; to become thick, stiff, hard', see I.4);

e. 'to have pleasant taste' — 'to be good' (PS * tyb, see I.5);

f. 'to have pleasant or sweet taste' $>$ 'salt' (Akk. tābtu 's.th. having pleasant taste' > 'salt', see I.5);

g. 'to be bitter' > 'to be unpleasant, pungeant, sharp (words)' (Tna. märrir 'sour; biting, sharp (words)', Arb. Pamarra 'to make bitter; to say bitter things', Hbr. morōrōt 'bitter things' < mrr 'to be bitter', see I.6.d);

h. 'to be sweet' > 'to be unfermented (drink), unleavened (dough)' (Hbr. pB. mətīka 'sweet taste; sweet drinks', and the term for unleavened bread in Tna. and Amh., related to the same root, see I.7);

i. 'to be sweet' > 'to be good, becoming, beautiful' (Tna. Pamiarä 'to make sweet; to be good for, be becoming', see I.3; Amh. kəsəm 'pleasing, dignified presence or appearance' < '(pleasant) taste'; possibly also Har. täkèmäsa 'become beautiful', (a)kōmäsa 'be beautiful' $<* k m s$ 'to taste, to have good taste', see I.8);

k. 'to have the taste of s.th.' $>$ 'to remind someone of s.th., to seem s.th.' (Tna. kəmso 'taste; example or sample', see I.8; Tna. tä̊amä 'to taste; to have pleasant taste; to remind of s.th., to seem s.th.', see I.9).

\section{References}

J. BARTH, 1967. Die Nominalbildung in den Semitischen Sprachen, Hildesheim.

B. BERLIN - P. KAY, 1969. Basic colour terms: their universality and evolution, Berkeley.

M. BulaKH (forthcoming). «Basic colour terms in Geez: synchronic and diachronic aspects», in: S. Uhlig et al (eds.), Proceedings of the $X V^{\text {th }}$ International Conference of Ethiopian Studies, Wiesbaden.

I. Gruntov (ms.). И. Грунтов, «Системы номинации вкусов: синхрония и диахрония» (Systems of taste nomination: synchronical and diachronical approach).

D. PARdeE, 1978. «The Semitic Root $m r r$ and the Etymology of Ugaritic $m r(r) / /$ brk», Ugarit-Forschungen 10: 249-288.

F. Praetorius, 1890. «Beiträge zur äthiopischen Grammatik und Etymologie (II)», Beiträge zur Assyriologie und vergleichenden semitischen Sprachwissenschaft 1: 369-378.

M. RAZUVAEv, 2004. М. РАзУВАEB, Деривационный потенциал значений «резать» и «рвать» в английском и русском языках (Semantic derivational valency of verbs with primary meanings «to cut» and «to tear» in Russian and English languages), Ph.D. thesis, Voronezh State University. 
E. VIBERG, 1984. «The verbs of perception: a typological study», in: B. Butterworth - B. Comrie - Ö. Dahl (eds.), Explanations for language universals, Berlin, 123-162.

A. WierzBicka, 1996. Semantics: Primes and Universals, Oxford - New York.

J. M. Williams, 1976. «Synasthetic Adjectives: A Possible Law of Semantic Change», Language 52, no. 2: 461-478.

A. ZaLIZNIAK, 2001. А. ЗАлизняк, «Семантическая деривация в синхронии и диахронии: проект “Каталога семантических переходов”》 (Semantic derivation in synchronic and diachronic aspect: project «Catalogue of semantic shifts»), Вопросы языкознания 2: 13-25.

\section{Sources}

\section{Dictionaries:}

[AHw.] - W. von Soden, 1965-1981. Akkadisches Handwörterbuch, Wiesbaden.

[BDB] - F. Brown - S. R. Driver - Ch. A. Briggs, 1951. A Hebrew and English Lexicon of the Old Testament, Oxford.

[BK] — A. DE Biberstein-KAZIMIRSKI, 1860. Dictionnaire arabe-français, vol. I, II, Paris.

[Brock.] - C. Brockelmann, 1928. Lexicon Syriacum, Halle.

[CAD] — L. Oppenheim - E. Reiner - M. T. Roth (eds.). 1956ff. The Assyrian Dictionary of the Oriental Institute, the University of Chicago, Chicago.

[DM] - E. S. Drower — R. Macuch, 1963. A Mandaic Dictionary, Oxford.

[DUL] - G. Del Olmo Lete - J. Sanmartín, 2003. A dictionary of the Ugaritic language in the alphabetic tradition, Leiden - Boston.

[Gragg] — G. GRaGG, 1982. Oromo Dictionary, Michigan.

[Grébaut] - S. GRébaut, 1952. Supplément au Lexicon Linguae Aethiopicae de August Dillmann (1865) et Édition du Lexique de Juste d'Urbin (1850-1855), Paris.

[HALAT] — L. Koehler — W. BaumgarTner, 1974-1990. Hebräisches und Aramäisches Lexikon zum Alten Testament (neu bearbeitet von W. Baumgartner), Leiden.

[HALOT] — L. KoEHLER et al., 1994-2000. The Hebrew and Aramaic Lexicon of the Old Testament, transl. and edited by M. Richardson, Leiden.

$[\mathrm{HJ}]$ - J. HoftIZZeR - K. Jongeling, 1995. Dictionary of the North-West Semitic Inscriptions, Leiden - New York - Köln.

[Hud] — G. Hudson, 1989. Highland East Cushitic Dictionary, Hamburg (Kuschitische Sprachstudien 7). 
[Ja.] - M. Jastrow, 1926. A Dictionary of the Targumim, the Talmud Babli and Yerushalmi, and the Midrashic literature, N. Y.

[JH] — T. M. Johnstone, 1977. Harsūsi Lexicon, Oxford.

[JJ] — T. M. Johnstone, 1981. Jibbāli Lexicon, Oxford.

[JM] — T. M. Johnstone, 1987. Mehri Lexicon, London.

[K] — T. L. Kane, 1990. Amharic-English Dictionary, vol. I, II, Wiesbaden.

[KT] - T. L. KANE, 2000. Tigrinya-English Dictionary, vol. I, II, Springfield.

[Lane] - E. W. LANE, 1863-1893. Arabic-English Lexicon, London (repr. New York, 1955-1956).

[LArg.] — W. Leslau, 1997. Ethiopic Documents: Argobba. Grammar and Dictionary, Wiesbaden (Aethiopistische Forschungen 47).

[LGaf.] - W. Leslau, 1956. Étude descriptive et comparative du Gafat (Éthiopien méridional), Paris (Collection Linguistique publiée par la Société de Linguistique de Paris 57).

[LGur.] - W. LesLau, 1979. Etymological Dictionary of Gurage (Ethiopic), vol. III, Wiesbaden.

[LGz.] - W. Leslau, 1987. Comparative Dictionary of GeYez (Classical Ethiopic), Wiesbaden.

[LH] — E. LitTMANN - M. HöFNER, 1956. Wörterbuch der Tigrē-Sprache, Wiesbaden.

[LHar.] - W. LeSlau, 1963. Etymological Dictionary of Harari, Berkeley — Los Angeles.

[LLA] - A. Dillmann, 1865. Lexicon Linguae Aethiopicae cum indice latino, Leipzig (repr. New York 1955).

[LS] — W. Leslau, 1938. Lexique Soqotri, Paris.

[Reinisch 1885] — L. REINISCH, 1885. Die Quarasprache in Abessinien, vol. II, Wien.

[Reinisch 1890] — L. ReINISCH, 1890. Die Saho-Sprache, II: Wörterbuch der Saho-Sprache, Wien.

[Sasse] - H.-J. SASSE, 1982. An Etymological Dictionary of Burji, Hamburg (Kuschitische Sprachstudien 1).

[SED] - L. E. Kogan - A. Yu. Militarev, 2000. Semitic Etymological Dictionary, vol. I.: Anatomy of Man and Animals, Münster.

[SD] - A. F. L. BeEston et al., 1982. Sabaic Dictionary, Louvain-laNeuve.

[Sokoloff] - M. Sokoloff, 2002. A Dictionary of Jewish Palestinian Aramaic, Baltimore — London.

[T] — R. S. Tомваск, 1978. A Comparative Semitic Lexicon of the Phoenician and Punic Languages, Missoula.

[Tal] - A. TAL, 2000. A Dictionary of Samaritan Aramaic, vol. I, II, Leiden - Boston — Köln (Handbuch der Orientalistik 50). 
[Vasmer] - M. VASMER, 1955. Russisches etymologisches Wörterbuch, vol. 2, Heidelberg.

\section{Texts:}

K. Elliger — W. RudolPh (eds.), 1969-1977. Biblia Hebraica Stuttgartensia, Stuttgart.

A. RAHLFS (ed.), 1940. Septuaginta, vol. I, II. editio tertiae. Stuttgart.

E. A. W. Budge, 1906. The Life of Takla Hâymânôt in the Version of Dabra Libanôs, and the Miracles of Takla Hâymânôt in the Version of Dabra Libanôs, and the Book of the Riches of Kings, 2 vols., London.

A. Dillmann, 1853. Veteris Testamenti Aethiopici, vol. I: Tomus primus, sive Octateuchus Aethiopicus, Leipzig.

A. Dillmann. 1894. Veteris Testamenti Aethiopici, vol. V: Tomus Quintus, quo continentur Libri Apocryphi. Baruch, Epistola Jeremiae, Tobith, Judith, Ecclesiasticus, Sapientia, Esdrae Apocalypsis, Esdrae Graecus, Berlin.

K. FrIEs, 1892. Weddāsē Mārjām. Ein Äthiopischer Lobsgesang an Maria, Leipzig.

A. Grohmann, 1919. Aethiopische Marienhymnen, Leipzig.

I. Guid, 1909. Le Synaxaire Éthiopien. Les mois de Sanê, Hamlê et Nahasê. II. Mois de Hamlê, Paris (PO 7, fasc. 3).

M. A. KniBb, The Ethiopic Book of Enoch, vol. I, II, Oxford, 1978.

R. Zuurmond, 2001. Novum Testamentum Aethiopice. Part III: The Gospel of Matthew, Wiesbaden (Äthiopistische Forschungen 55).

\section{Abbreviations:}

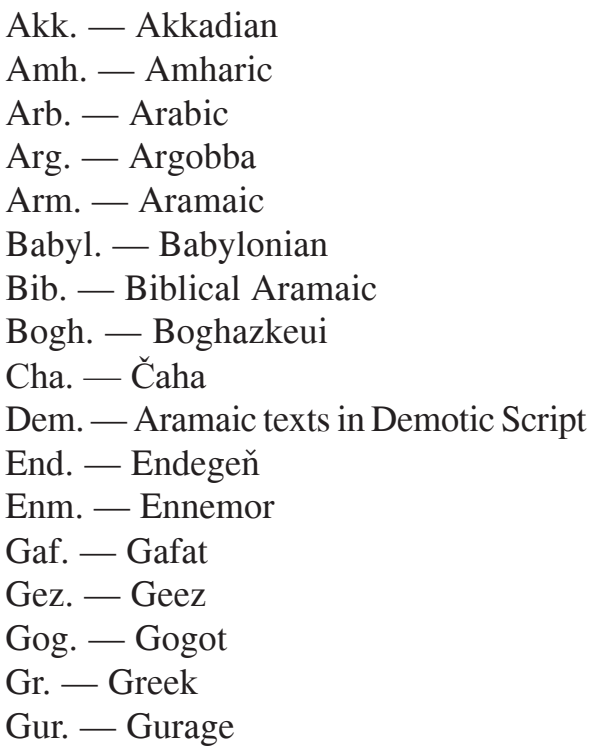

Gyt. - Gyeto

Har. - Harari

Hbr. - Hebrew

Hrs. - Harsusi

Jib. — Jibbali

JPA — Jewish Palestinian Aramaic

Jud. - Judaic Aramaic

LB - Late Babylonian

lex. - lexical (texts)

MA - Middle Assyrian

MB - Middle Babylonian

Mhr. - Mehri

Mnd. - Mandaic

Msq. - Masqan

Muh. - Muher

NA - Neo-Assyrian

Nab. - Nabatean 
NB - Neo-Babylonian

OA - Old Assyrian

OAkk. — Old Akkadian

OB - Old Babylonian

Off. - Official Aramaic

Old. - Old Aramaic

Palm. - Palmyrean

pB. - Post-biblical Hebrew

Pho. - Phoenician

PS - Proto-Semitic

Sab. - Sabaic
Sam. - Samaritan Aramaic

SB - Standard Babylonian

Sel. - Selți

Sod. - Soddo

Soq. - Soqotri

Syr. - Syriac

Tgr. - Tigre

Tna. - Tigrinya

Ugr. - Ugaritic

Wol. - Wolane

Zwy. - Zway

\section{SUMMARY}

The paper gives a survey of Geez lexemes belonging to the lexical field of taste, discussing each in terms of its usage in Geez texts and its etymology. The semantic shifts occuring both on a synchronic level (as polysemy) and on a diachronic level (as differences in meaning between cognates) receive special attention. Whenever possible, parallel semantic developments from other (as a rule, Semitic) languages are adduced. A list of the registered semantic shifts is given in the second part of the paper. 